\title{
Sudden Unexpected Death in Epilepsy: A Case Report
}

\author{
Epilepside Ani Beklenmedik Ölüm (SUDEP): \\ Bir Olgu Sunumu
}

\section{Gülser KARADABAN EMIR, Yasemin ÜNAL, Dilek ASLAN ÖZTÜRK, Gülnihal KUTLU}

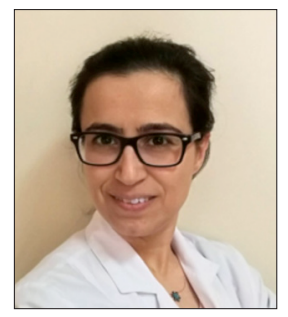

Gülser KARADABAN EMIR, M.D.

Department of Neurology, Muğla Sıtkı Koçman University Faculty of Medicine, Muğla, Turkey

\section{Summary}

Sudden unexpected death in epilepsy (SUDEP) is a serious problem, and its importance has increased in recent years. It is responsible for the death of $17 \%$ of epilepsy patients. As the age of onset rises, the risk increases. Patients with refractory epilepsy are particularly at risk. Likewise, male gender, early age of onset, polytherapy, nocturnal seizures, generalized tonic-clonic seizures (GTCS) are also among the risk factors. Respiratory, cardiac, autonomic and brain stem related pathologies are held to be responsible for its pathophysiology.

Key words: Death; SUDEP; temporal lobe epilepsy.

\section{Özet}

Epilepside ani beklenmedik ölüm (SUDEP) son yıllarda önemi artan ciddi bir problemdir. Epilepsi hastalarındaki ölümlerin \%17'sinden sorumludur. Hastalık yaşı arttıkça risk artmaktadır. Özellikle dirençli epilepsi hastaları risk altındadır. Ayrıca erkek cinsiyet, erken yaşta başlangıç, politerapi, nokturnal nöbetler, jeneralize tonik klonik nöbetler de risk faktörleri arasındadır. Patofizyolojisinde solunumsal, kardiyak, otonomik ve beyin sapı ile ilgili patolojiler sorumlu tutulmaktadır.

Anahtar sözcükler: Ölüm; SUDEP; temporal lob epilepsi.

\section{Introduction}

Epilepsy is a disease characterized by recurrent seizures. ${ }^{[1]}$ Deaths in epilepsy may occur during status epilepticus, as accidents or drowning in water caused by the seizure, and as a sudden unexpected death in epilepsy (SUDEP). ${ }^{[2]}$ Compared with the general population, the risk of SUDEP is 20 times higher in epilepsy patients, ${ }^{[3]}$ and it is estimated that SUDEP is responsible for about $17 \%$ of deaths. ${ }^{[4]}$ SUDEP is responsible for $24-67 \%$ of seizure-related deaths. ${ }^{[2]}$

SUDEP was initially recognized in the nineteenth century, but in the last two decades it has become better understood, and awareness of it has increased. ${ }^{[5]}$ It is defined as the sudden, unexpected, witnessed or unwitnessed, non-traumatic, and non-drowning death of patients with epilepsy, with or without evidence of a seizure, excluding documented status epilepticus, and in which the postmortem examination does not reveal a structural or toxicological cause of death. ${ }^{[6]}$

\section{Case Report}

A 39-year-old male patient was admitted to the emergency department due to contraction in the whole body and unconsciousness. There was no one who clearly witnessed the beginning of the seizure. His relatives reported that the contraction lasted about 10 minutes and then the patient had not regained consciousness for half an
Submitted (Geliş): 11.08.2016

Accepted (Kabul) : 27.03.2017

Correspondence (illetişim): Gülser KARADABAN EMIR, M.D. e-mail (e-posta): g_karadaban@hotmail.com 
hour. The patient had not been previously diagnosed with epilepsy. However, it was learned that he had fainted two months earlier, in the same way. Apart from this, he also had a drug intoxication history seven years previously. The patient's neurological examination was normal. The physical examination was normal, except for erosion due to biting on the left half of the tongue. The patient was hospitalized in the neurology department for an further investigation. Cranial computed tomography (CT) and magnetic resonance imaging (MRI) revealed no significant pathology. In blood tests, complete blood counts, renal function tests, liver function tests, electrolytes, and thyroid function tests were within normal limits. Electroencephalography (EEG) revealed isolated sharp characteristic waves in the left temporal region. Valproic acid (VPA) treatment was initiated for the patient, and the dose was gradually increased to $1500 \mathrm{mg} /$ day. Carbamazepine was added to the treatment due to his having had one or two seizures in a month. During follow-up, it was learned that the patient did not use carbamazepine due to the side effects. The patient was hospitalized again with the complaint of suffering seizure after 2.5 months. The patient's neurological examination was normal. Levetiracetam (LEV) of $1000 \mathrm{mg} /$ day was added to the VPA treatment of $1500 \mathrm{mg} /$ day. Patient's recurrent cranial CT showed no pathology. The patient had burns on the left upper extremity due to falling onto the stove at home. The patient was discharged with $1500 \mathrm{mg} /$ day VPA and $1000 \mathrm{mg} /$ day LEV. Four months after his discharge, he was found dead at home and an autopsy was performed. The autopsy result was expressed as: "In an external examination and autopsy of the deceased, no sharp object injuries and no fatal assault or gunshot injuries were observed apart from bruiserelated findings." The SUDEP diagnosis became definite with the medical opinion report stating that the person died due to his disease since toxicological examinations revealed no agent other than 0.42 promile ethyl alcohol and the ratio of ethyl alcohol detected was not at a level to cause death.

\section{Discussion}

The definition of SUDEP was first described by Nashef In 1997 ${ }^{[6]}$ and in 2011 under the International League Against Epilepsy (ILAE) framework the definition of SUDEP has been reviewed by Nashef et al., and a new definition-classification proposal has been introduced. According to this proposal, SUDEP is divided into six groups as follows: i) Definite SUDEP: Sudden, unexpected, witnessed or unwitnessed, non-traumatic, and non-drowning death of patients with epilepsy, with or without evidence of a seizure, and without status epilepticus. Likewise, on postmortem examination, there should be no other cause of death. ii) Probable SUDEP: The same as with Definite SUDEP, but no autopsy is performed. iii) Possible SUDEP: There is another factor that competes with SUDEP as the cause of death. iv) Near SUDEP: While there is no structural cause in a patient with epilepsy, there arises a need for resuscitation for more than an hour following cardiorespiratory arrest. v) Not SUDEP: The presence of a clear, definite cause of death in a patient with epilepsy. vi) Unclassified: Death of a patient with epilepsy where classification is not possible due to lack of information. ${ }^{[7]}$

Considering this classification, our case was a Definite SUDEP. The autopsy In SUDEP is a guide for many factors In terms of exclusion and has an important place in the definite diagnosis. In a study by Güngör et al., ${ }^{[8]}$ SUDEP cases between 2003 and 2013 were reviewed, and it was reported that eight of the nine patients diagnosed with SUDEP were probable SUDEP, while one of them was possible SUDEP. The incidence of SUDEP varies slightly in community-based studies, and it is generally thought to be $0.35-1 / 1000 / y e a r$. The incidence rate is higher in special epilepsy groups and is reported to be 2-6/1000/year in epilepsy surgery candidates, patients included in new drug studies, and epilepsy patients who have undergone vagal stimulation. ${ }^{[9]}$ Incidence appears to be higher in patients with refractory chronic epilepsy. ${ }^{[2]}$ In these patients, the risk of SUDEP throughout their life is $30-40 \% .{ }^{[10]}$ Since this rate is very high, these patients should be followed up carefully for SUDEP.

Although SUDEP can be seen at any age, it is more common in the age range of 25-40. ${ }^{[2]}$ Early age of onset, male gender, epileptic seizure duration, polytherapy, nocturnal seizures, and GTCS are significant risk factors for SUDEP. The frequency of seizures and the number of antiepileptic drugs used by epilepsy patients with SUDEP have been reported to be higher; however, no relationship has been shown between the type of anti-epileptic drug used and SUDEP. [11] Our case was a 30-year old male, who was having frequent seizures, had a further seizure within 2.5 months and was hospitalized accordingly. Considering these factors, our case had the relevant risk factors. 
Pathophysiology of SUDEP is not fully understood, but it is thought that there may be underlying reasons relatedto cardiac, respiratory, autonomic, or brainstem pathologies. ${ }^{[12]}$

The study by Ryvlin et al. ${ }^{[13]}$ provided new insights into the incidence and mechanisms of seizure-related cardiorespiratory arrest regarding the pathophysiology of SUDEP. They examined cardiorespiratory data of 10 SUDEP cases and reported that tachypnea developed in these cases after the secondary generalized seizure, cardiorespiratory dysfunction was observed in following 3 seconds and cardiac arrest was developed within 11 seconds following the seizure with terminal apnea.

Seizure activity may lead to cardiac arrhythmia, blood pressure changes and asystole. Besides, respiratory depression and apnea following seizures may lead to oxygen desaturation. ${ }^{[14]}$

Respiratory depression that occur in the peri-ictal period may cause secondary cardiac insufficiency. When seizures with and without oxygen desaturation were compared, it was shown that the probability of the prolongation of the QT interval was four times greater in seizures with oxygen saturation less than $90 \% .{ }^{[15]}$ In a study by Bateman et al., oxygen saturation was reported to be less than $90 \%, 80 \%$, and $\% 70$ in $33.2 \%, 10.2 \%$, and $3.6 \%$ of the seizures, respectively. When the airflow measurements of 100 seizures were examined, central apnea and hypopnea were observed in half the seizures, whereas mixed or obstructive apnea was observed in $9 \%$ of them. In seven patients, end-tidal $\mathrm{CO}^{2}$ values were found to be increased, and this was found to be associated with oxygen desaturation of less than $85 \%$. ${ }^{[16]}$

Pulmonary edema may also be involved in the pathophysiology of SUDEP. Pulmonary edema has been detected in autopsy cases. ${ }^{[14]}$ In SUDEP cases, neurogenic pulmonary edema is an important pathological sign. Systemic and adrenergic stimulation with a massive central source plays a role in the occurrence of neurogenic pulmonary edema. If pulmonary edema is not treated, it will result in death due to high mortality rates. ${ }^{[12]}$ In the autopsy that was performed for our case, no pathology was observed except for color changes due to decay in the external appearance and several sections of the lungs.

In SUDEP pathophysiology, heart rate variability (HRV) is also emphasized. HRV depends on sinoatrial nodal modu- lation by the autonomic nervous system. ${ }^{[17]}$ Compared with the general population, HRV is decreased in patients with temporal lobe epilepsy. This reduction is more evident at night. A decrease in heart rate variability increases cardiac mortality and sudden cardiac death. ${ }^{[14]}$ The EEG of our case revealed isolated sharp waves in the left temporal lobe, which suggests temporal lobe epilepsy. The shortening of the QT interval indicates abnormal cardiac repolarization. The short QT interval is important for SUDEP because it poses a risk of sudden cardiac death. ${ }^{[18]}$

Consciousness changes in the post-ictal period also cause a risk of SUDEP. In particular, GTCS and complex partial seizures are accompanied by a loss of consciousness, and this may lead to SUDEP, as a result of the loss of protective reflexes. ${ }^{[14]}$ In our case, the seizures were accompanied by a loss of consciousness. He had fallen several times due to loss of consciousness, and on one occasion burns occurred on the left upper extremity due to falling.

Serotonin (5HT) plays an important role in the pathophysiology of SUDEP since it is of critical importance in respiratory control. A defect in the $5 \mathrm{HT}$ system is a risk factor for SUDEP. Stimulation of $5 \mathrm{HT}$ in mouse models with $5 \mathrm{HT}$ defects helps to reduce hypoventilation and death. ${ }^{[14,19]}$ Serotonin is known to play an important role in sudden infant death syndrome, which is thought to have similar pathogenesis with SUDEP. ${ }^{[1,20]}$

In the pathophysiology of SUDEP, Video-EEG monitoring is important for the diagnosis of peri-ictal respiration disorders. It sheds light on the diagnosis of respiratory and cardiac problems that occur during the peri-ictal period. We can not receive any information about respiratory events directly in the video-EEG monitorization, however, an effort to breath at that time and EEG artefacts may assist to determine a respiration disorder. ${ }^{[19]}$ Our case did not have a video-EEG recording.

It is important to take precautions to reduce SUDEP since it is a serious cause of death in epilepsy. Therefore, GTCS, which is the most common cause of SUDEP, should be treated effectively. Additionally, the patient should be informed regarding the factors that trigger seizures (e.g. insomnia, alcohol, other medicines that lower the seizure threshold) as well as factors that lower blood levels of antiepileptic drugs, such as gastrointestinal disease, pregnancy, and oral contraceptive use. Patients with epilepsy who have a SUDEP 
risk should be evaluated for surgery at the appropriate time, because successful curative surgery provides effective protection against SUDEP. ${ }^{[2]]}$

In a study conducted by Liebenthal et al., ${ }^{[22]}$ lying positions of 253 SUDEP cases were examined and $73.3 \%$ were reported to die in the prone position while $26.7 \%$ died in other positions. When the prone position and other positions were compared, the relationship between the prone position and SUDEP was found to be significant. Therefore, patients should be informed and warned about the risks of lying in a prone position.

In conclusion, SUDEP is rather a perturbing condition for patients and their families. Hence, patients with epilepsy should be controlled carefully regarding SUDEP risk, and patients and their relatives should be informed about this subject. The risk of SUDEP should always be kept in mind, particularly in patients with GTCS and refractory epilepsy. Patients should be screened to determine risk factors, and precautions should be taken in this regard.

\section{Peer-review}

Externally peer-reviewed.

\section{Conflict of interest}

None declared.

\section{Authorship Contributions}

Concept: G.K., Y.Ü.; Supervision: G.K.E., D.A.Ö.; Data collection \&/or processing: Y.Ü., G.K.E.; Literature search: G.K.E.; Writing: G.K.

\section{References}

1. Şahiner T. Epilepside Temel Mekanizmalar: İçinde: Bora I, Yeni N, Gürses C editörler. Epilepsi. 1. Baskı. İstanbul: Nobel Tıp Kitabevleri; 2008. s. 29-36.

2. Bora İ. Epilepsi ve Mortalite. İçinde: Bora İ, Yeni N, Gürses C editörler. Epilepsi. 1. Baskı. İstanbul: Nobel Tıp Kitabevleri; 2008. S.81-5.

3. Ficker DM, So EL, Shen WK, Annegers JF, O'Brien PC, Cascino $\mathrm{GD}$, et al. Population-based study of the incidence of sudden unexplained death in epilepsy. Neurology 1998;51(5):1270-4.

4. Hughes JR. A review of sudden unexpected death in epilepsy: prediction of patients at risk. Epilepsy Behav 2009;14(2):280-7.

5. Tomson T, Sveinsson O. Sudden Unexpected Death in Epilepsy (SUDEP): An Overview. Epilepsi 2013;19(3):91-96. [CrossRef]

6. Nashef L. Sudden unexpected death in epilepsy: terminology and definitions. Epilepsia 1997;38(11 Suppl):S6-8. [CrossRef]
7. Nashef L, So EL, Ryvlin P, Tomson T. Unifying the definitions of sudden unexpected death in epilepsy. Epilepsia 2012;53(2):227-33. [CrossRef]

8. Güngör M, Acar Arslan E, Tezer Filik Fi, Saygı S. SUDEP: The First Case Series in Turkey. Arch Neuropsychiatry 2016;53:67-71.

9. Walczak TS, Leppik IE, D'Amelio M, Rarick J, So E, Ahman P, et al. Incidence and risk factors in sudden unexpected death in epilepsy: a prospective cohort study. Neurology 2001;56(4):519-25.

10. Shankar R, Cox D, Jalihal V, Brown S, Hanna J, McLean B. Sudden unexpected death in epilepsy (SUDEP): development of a safety checklist. Seizure 2013;22(10):812-7. [CrossRef]

11. Ryu HU, Hong JP, Han SH, Choi EJ, Song JH, Lee SA et al. Seizure Frequencies and Number of Anti-epileptic Drugs as Risk Factors for Sudden Unexpected Death in Epilepsy. J Korean Med Sci 2015;30(6):788-92. [CrossRef]

12. Gürses C. SUDEP-Epilepsi Hastalarında Ani Beklenmedik Ölüm. Turkiye Klinikleri J Neurol-Special Topics 2012;5(1):52-5

13. Ryvlin $P$, Nashef $L$, Lhatoo SD, Bateman LM, Bird J, Bleasel A, et al. Incidence and mechanisms of cardiorespiratory arrests in epilepsy monitoring units (MORTEMUS): a retrospective study. Lancet Neurol 2013;12(10):966-77. [CrossRef]

14. Massey CA, Sowers LP, Dlouhy BJ, Richerson GB. Mechanisms of sudden unexpected death in epilepsy: the pathway to prevention. Nat Rev Neurol 2014;10(5):271-82. [CrossRef]

15. Seyal M, Pascual F, Lee CY, Li CS, Bateman LM. Seizure-related cardiac repolarization abnormalities are associated with ictal hypoxemia. Epilepsia 2011;52(11):2105-11. [CrossRef]

16. Bateman LM, Li CS, Seyal M. Ictal hypoxemia in localization-related epilepsy: analysis of incidence, severity and risk factors. Brain 2008;131(Pt 12):3239-45. [CrossRef]

17. Stein PK, Kleiger RE. Insights from the study of heart rate variability. Annu Rev Med 1999;50:249-61. [CrossRef]

18. Jeppesen J, Fuglsang-Frederiksen A, Brugada R, Pedersen B, Rubboli $G$, Johansen $P$, et al. Heart rate variability analysis indicates preictal parasympathetic overdrive preceding seizureinduced cardiac dysrhythmias leading to sudden unexpected death in a patient with epilepsy. Epilepsia 2014;55(7):e67-71.

19. Kennedy JD, Seyal M. Respiratory pathophysiology with seizures and implications for sudden unexpected death in epilepsy. J Clin Neurophysiol 2015;32(1):10-3. [CrossRef]

20. Richerson GB, Buchanan GF. The serotonin axis: Shared mechanisms in seizures, depression, and SUDEP. Epilepsia 2011;52 Suppl 1:28-38. [CrossRef]

21. Ryvlin $P$, Nashef $L$, Tomson T. Prevention of sudden unexpected death in epilepsy: a realistic goal? Epilepsia 2013;54 Suppl 2:23-8.

22. Liebenthal JA, Wu S, Rose S, Ebersole JS, Tao JX. Association of prone position with sudden unexpected death in epilepsy. Neurology 2015;84(7):703-9. [CrossRef] 